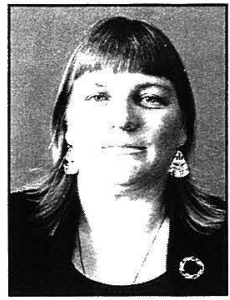

\title{
AN ANALYSIS OF PERSONAL GRIEVANCE STATISTICS IN NEW ZEALAND FROM 1984 TO 1998
}

\author{
Dianne Donald and Joanna Cullinane
}

University of Waikato

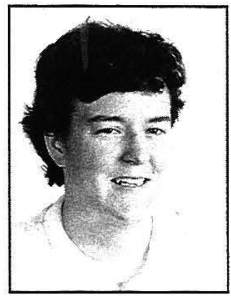

\section{Abstract}

Personal grievance procedures have been a part of New Zealand's industrial relations system since 1973. Initially these procedures were limited in availability to those employees who were members of unions and subject to a union negotiated document. Since the enactment of the Employment Contracts Act 1991 (ECA), personal grievance procedures have become available to all New Zealand employees. It is interesting to note that at the same time, unions' roles in industrial relations have diminished and progressively fewer employees know their rights in employment.

This paper analyses the statistical data from the Department of Labour on personal grievance cases resolved by the specialist employment institutions between 1984 and 1998. The paper also notes the changes in types of personal grievances and the rates of growth and decline in personal grievance cases. Two important facts have been identified. The first involves the large increase in the number of personal grievance cases taken to the specialist institutions since the ECA came into force. The second issue is the large proportion of unjustified dismissal cases that make up the body of the personal grievance cases. Finally, this paper explores some explanations for the movements noted in personal grievance data as a precursor to further research.

Keywords: personal grievances, time series analysis, Employment Tribunal

According to the Report of the Department of Labour for the year ended 30 June 1998, the Employment Tribunal resolved 3420 personal grievances in the 1997-98 year. Hence, it can be argued that as a significant number of employees chose to use the personal grievance provisions, it is important for industrial relations practitioners and scholars to understand the statistical details of personal grievances in New Zealand. This paper will proceed by briefly describing personal grievances in New Zealand industrial relations. Next an outline of the method of data collection and interpretation will be provided. The findings will then be presented in detail. The paper will conclude with implications for future research.

\section{Personal grievances in New Zealand}

New Zealand labour legislation first distinguished between interest and rights disputes in the Industrial Relations Act (1973). Interest disputes, or those concerning contract negotiations, were separated from rights disputes, those associated with contract interpretation or administration. At this time, the distinction led to the introduction of personal grievance provisions for union members covered by a union negotiated document (Deeks, Parker \& Ryan, 1996; Spell, 1998). Almost 20 years later the Employment Contracts Act 1991 (ECA) made three changes to the grievance procedures available to New Zealand employees. The most notable change was the extension of grievance procedure access to all employees (Grills, 1994; Hughes, 1993) through the stipulation that all employment contracts were required to include a procedure for addressing personal grievances (Oldfield \& Ryan, 1991). Also changed are the procedure itself and the remedies provided for proven grievances (Deeks, Parker \& Ryan, 1996).

The essence of what constitutes a personal grievance has not altered with the ECA, it still relates to contract interpretation or administration, or rights disputes. Section 27 of the ECA defines a personal grievance as a claim by a employee that an employer has caused disadvantage on one or more of five grounds: unjustifiable dismissal; unjustifiable action leading to disadvantage; discrimination; sexual harassment; or; duress (Deeks, Parker \& Ryan, 1996; Oldfield \& Ryan, 1991). Importantly, Deeks, Parker and Ryan (1996) identify the ECA personal grievance provisions as the chief protection of individuals against the arbitrary actions of strongly placed employers. Hence, personal grievances have the important functions of both allowing an opportunity for employees to express their unhappiness with a given situation and providing a method for resolving the dispute.

New Zealand currently has two specialist legal institutions to interpret and administer the Employment Contracts Act in general and employment contracts in particular, these are: the Employment Tribunal and the Employment Court. Section 76 of the ECA places the formal jurisdiction for 
personal grievances with the Employment Tribunal. The Tribunal is a low level institution established to "provide speedy, fair and just resolution of differences between parties to employment contracts, it being recognized that in some cases mutual resolution is either inappropriate or impossible" (ECA, Section 76 (c)).

The intention was for the Tribunal to be informal in nature; therefore, legal representation was not required. Members of the Tribunal tend to be people of considerable labour experience, either as industrial relations practitioners (such as union officials or managers) or as employment lawyers (Deeks, Parker \& Ryan, 1991). The Tribunal was designed to maintain effective employment relations through assisting employees and employers to resolve their differences through mediation. Tribunal members can adjudicate on disputes that cannot be settled by agreement (Deeks, Parker \& Ryan, 1996). However, the same member may not mediate and adjudicate the same case (Hughes, 1991). In particular, the Tribunal has formal jurisdiction over:

- Interpretation, application or operation of employment contracts

- Recovery or unpaid wages

- Penalties for breaches of the Employment Contracts Act

- Breach of employment contracts

- Personal grievances

- Questions regarding the construction of any relevant acts, such as the Holidays Act, the Minimum Wage Act

- Requests to make compliance orders (Oldfield \& Ryan, 1991, p. 73)

Judgements of the Tribunal are binding and enforceable through the Employment Court. Resolution through mediation is considered final as it has the agreement of both parties at the time of resolution. Adjudicated resolutions can be appealed though the Employment Court.

There is currently strong debate in New Zealand concerning the need for specialist institutions at all. This debate began with the drafting of the Employment Contracts Bill. People on one side of the debate argue that the employment relationship is not simply another form of commercial contract. Therefore, the retention of specialist institutions is necessary to address the inevitable conflict. In contrast, people with the opposing view argue that "judicial intervention is philosophically inconsistent with the free market principles underpinning the Act. Under a deregulated system ... the market would replace the courts as the sole arbiter of justice" (Skiffington, 1996, p. 50).

The debate continues today, with opponents of the specialist institutions arguing that any conflict arising from an employment contract should be referred to the general courts system, and judged according to contract and tort law, just like any other contract. Rather than removing the institutions altogether, some propose limiting access to the personal grievance provisions according to length of em- ployment. For example, only those employees employed for six months or longer may take a personal grievance. Accordingly, the current Ministry of Labour has been instructed by the government to investigate and report on the need for state intervention through specialist legal institutions in New Zealand industrial relations.

\section{Conducting research on personal grievance statistics}

An empirical analysis of cases of personal grievance in New Zealand is fraught with difficulty. The Department of Labour has included statistics on personal grievances in their annual reports since 1981, but the manner of recording these statistics has been inconsistent over time. An added difficulty in interpreting personal grievance statistics over a time series has arisen through the major changes to the industrial relations framework over time. This study spans three acts governing industrial relations, including; the Industrial Relations Act 1973, the Labour Relations Act 1987 and the Employment Contracts Act 1991. Each of these acts heralded a new industrial relations legal system.

Under the Industrial Relations Act 1973, the specialist institutions governing disputes in industrial relations were the Arbitration Court, the Industrial Conciliation Service and the Industrial Mediation Service (DoL, 1982). Personal grievances were the domain of the Industrial Conciliation Service and the Industrial Mediation Service, hence data reported in this paper that relate to personal grievances which fall between 1973 and 1987 are a combination of statistics on cases dealt with by both of these services.

On the 1 August 1987, the provisions of the Labour Relations Act 1987 brought a change to the specialist institutions in industrial relations. The Arbitration Court was replaced by the Labour Court and the Arbitration Commission and the Industrial Conciliation Service and the Industrial Mediation Service were combined into the Mediation Service which gained primary jurisdiction over personal grievances (DoL, 1987, 1988). Data relating to personal grievances that fall between 1987 and 1991 are taken from the work of the Mediation Service. Where the Department of Labour has noted that the "decision on personal grievance was made by the chairperson" we have treated the results as arbitration, and all other cases are treated as having been mediated.

On 19 August 1991, the Employment Contracts Act brought the most recent change to the specialist institutions in industrial relations - the Employment Court was established to replace the Labour Court and the Employment Tribunal was established to replace the Mediation Service. However, it should be noted that the mediation service remained operating until the close of business on the 31st of December 1991 to hear claims that were existing when the ECA came into operation on 15 May 1991. Between the enactment of the ECA on 15 May 1991 and the startup of the new institutions on 18 August 1991, the Labour Court acted as the Employment Tribunal on urgent matters. 
Figure 1. Total cases resolved through the Employment Tribunal

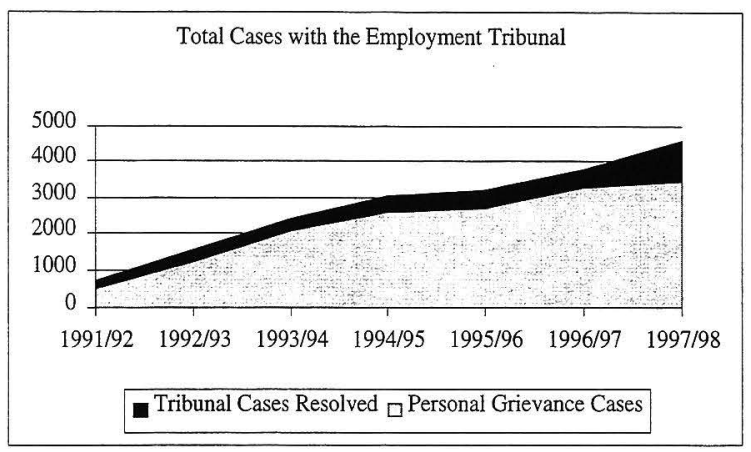

The Arbitration Commission ceased operating at the close of business on the 18th of August 1991, but was not replaced under the new ECA framework. Under this new framework, the Employment Tribunal gained primary responsibility for the resolution of personal grievance cases (DoL 1991). Data reported in this paper that relate to personal grievances that fall between 1991 and 1998 are taken from the work of the Employment Tribunal.

Most of the data on personal grievances presented in this paper is based on the 1990-1998 time period. While a longer timeframe for analysis was desirable, complete information on the number of cases of personal grievance by category of personal grievance type was not consistently recorded by the Department of Labour prior to 1990 . Hence, no data is reported in this paper which compares patterns within the categories of personal grievance prior to 1990 . It is with these limitations imposed by the variety of legal institutions and collection methods in mind, that we turn to the statistics to examine personal grievances in New Zealand.

\section{Personal grievance statistics in New Zealand and their implications}

In this section four aspects of personal grievance statistics in New Zealand will be illustrated graphically. More detail on the source of data for each graph is provided at the end of this paper. The four aspects are the work of the Employment Tribunal, time series analysis of personal grievances, personal grievances by grievance type, and method of resolution. The implications of each set of statistics are also examined in this section.

\section{The work of the Employment Tribunal}

Figure 1 (above) depicts the personal grievances resolved through the Employment Tribunal as a proportion of total cases resolved by the Tribunal. This graph does not depict data before 1991 because the number of total cases is difficult to ascertain.

The vast majority of Tribunal work is personal grievances. In the $1991 / 92$ year, $67 \%$ of all Tribunal work was personal grievances. By $1997 / 98$, that proportion had risen to $75 \%$. The $1997 / 1998$ figure had dropped off slightly from $1996 / 97$, which perhaps reflects the influence of the higher levels of industrial unrest that accompany election years. It is interesting to note that the total number of cases resolved by the Tribunal has been steadily increasing over the sevenyear period shown in this graph. As personal 'grievances are such a high proportion of these cases, it follows that the number of personal grievances has also been increasing. One reason for this increase in personal grievances could be that since the enactment of the Employment Contracts Act 1991, personal grievances are available to all New Zealand employees. By increasing the number of people eligible, it is reasonable to expect an increase in personal grievances filed and, in most cases, resolved.

The increase in both total cases and personal grievances resolved is interesting when graphed as a percentage change from previous year. Figure 2 (next page) shows that the total number of cases resolved by the Employment Tribunal increased at a very fast rate for the first two periods under scrutiny, with personal grievance cases increasing at an even higher rate. This initially high percentage change in the number of cases resolved by the Tribunal is to be expected given that the system of industrial relations introduced by the ECA was significantly different to the previous frameworks of industrial relations in New Zealand. Comparatively, from $1992 / 93$ to $1994 / 95$ personal grievances increased at a higher rate than the total cases. This changed in 1995/96 and 1996/97 when the two lines cross each other for the first time, indicating a decreased growth 
Figure 2. Percentage change from previous year: total cases resolved through the Employment Tribunal

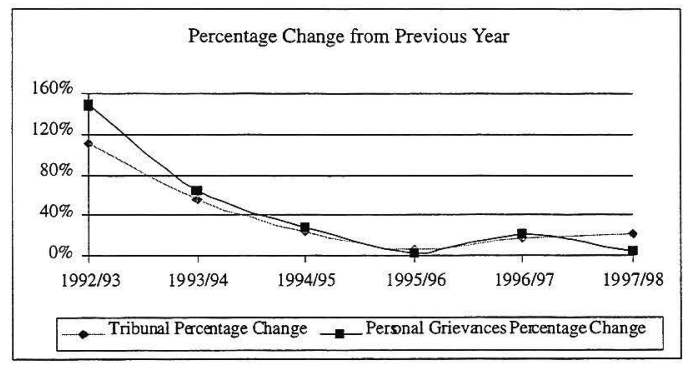

rate for personal grievances in comparison with the total followed immediately by a return to higher growth. In $1997 /$ 98 , personal grievances increased at a $20 \%$ lower rate than total cases. In essence, both total cases and personal grievances resolved are still increasing, but at different rates.

\section{Time series analysis of total personal grievances}

Figure 3 illustrates the number of personal grievance cases resolved between 1982/83 and 1997/98. As this graph is for total personal grievances resolved, available statistical information allows a longer time series for analysis. Therefore, this graph provides a 16 year context to the analysis of personal grievance cases resolved.

From $1982 / 83$ through to $1987 / 88$, personal grievances hovered around 500 per annum. There was a slight dip in the number of personal grievance cases resolved after the election of the Fourth Labour Government in 1984/85 which may have resulted from the attentions of the specialist institutions being focused on the lifting of the price and wage freeze. In the $1988 / 89$ year, personal grievances passed 600 for the first time during the span of this data. The number of personal grievance cases resolved continue to rise, peaking at 982 in the 1990/91 year. There are a number of possible explanations for this increase during the period when the Fourth Labour Government was in power. First, it could be that this was part of an existing trend, which indicates the frustration that employers and employees felt with the industrial relations climate at the time (Anderson, 1991; Boxall, 1993). Alternatively, the increase may reflect the growing confidence of employees in the industrial relations system after the end of a repressive era of government. Finally, the rise could simply reflect the fact that the Labour Government was putting more resources into industrial relations following the enactment of the Labour Relations Act. However, it must be noted that the last part of this rise in personal grievance cases resolved coincides with the

\section{Figure 3. Cases of personal grievance resolved through the Employment Tribunal}

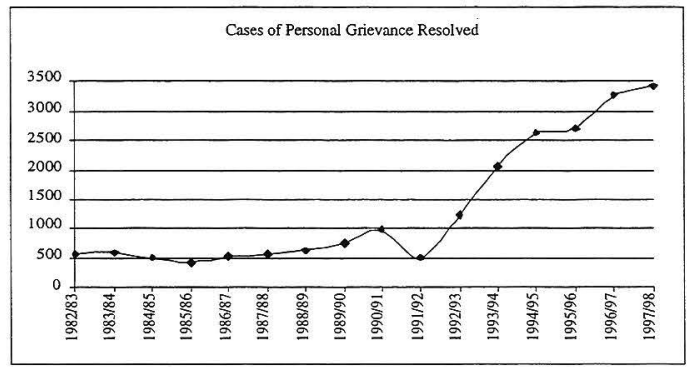


drafting of the Employment Contracts Bill. It is possible that union officials at that time considered the personal grievance provisions would most likely be removed under the new act, and filed personal grievances under the old legislation.

A striking feature of this graph is the dip in the 1991/92 year where personal grievances halved to a five year low of 500 resolutions. One reason for this dip could be that while new institutions were being set up and old ones were phased out, fewer cases were handled and therefore resolved. The players in the employment relationship also affect this figure on three counts. First, players needed to assess the new legislative environment before acting. Second, there was a lot of propaganda concerning the rights of employees under the new system. It may have taken a while for people to start filing actions under the new system. Finally, there may have been little immediate activity in the work environment that required legal action.

Personal grievances appear to rise significantly in the 1992 93 year, up almost $150 \%$ on the previous year (see Figure 4 above). It is interesting to note that this is only a $26 \%$ increase on the pre-ECA figure for 1990/91. This could relate to the employment relationship players having spent a year coming to terms with the new legislation. Another important factor was the increased number of people eligible to file a personal grievance. As noted earlier, under the ECA, personal grievances have become the chief protection of individuals against the arbitrary actions of strongly placed employers. At around the same time, the Department of Labour was also receiving a vastly increased number of telephone queries. In 1993, the Department of Labour was receiving 6000 complaints a month about breaches of minimum working conditions and issuing three times as many complaints as a year earlier" (Dannin, 1997, p. 172).

In the 1993/94 year, personal grievances continued to rise significantly which might be explained in a number of ways.
First, it is possible that employees were becoming more knowledgeable about their rights. For example, the Department of Labour telephone calls were a source of information for the average New Zealander. Also, the change in the industrial relations arena to focus on contracts would make individuals more aware of their own contract and its provisions. Alternatively, the increase in the number of personal grievance cases might reflect a rise in industrial activity that cycles with general elections.

The 1994/95 year saw a continuation of this upward movement, but at a reducing rate (see Figure 4). In essence, actual numbers of personal grievances continued to rise but not at the same speed. There was a corresponding rise in strike action. "Figures showed a steady increase in strikes each year, with a 36\% rise in 1994-1995 over the prior year" (Dannin, 1997, p. 179). It appears that employee representatives were becoming more aware of their ability to respond to the industrial relations situation.

The rise in personal grievances slowed significantly in the $1995 / 96$ year. This was immediately prior to a national election, which could account for reduced personal grievances as people waited for the election outcome before deciding a course of action.

Numbers jumped again in $1996 / 97$ with a $21 \%$ increase. The National Party was returned to power (albeit with a coalition partner) so no major changes to labour legislation were anticipated. Over this period, anecdotal evidence of the involvement of the Income Support Service began to arise. That is, people who were fired were advised to file a personal grievance in order to reduce the stand-down period before receiving an allowance. Additionally, as mentioned previously, industrial activity cycles with general elections, which could account for the increase in the number of personal grievance cases. Finally, $1997 / 98$ indicates another small rise in personal grievance resolutions. It is possible that the rise in personal grievances is flattening out with time.

\section{Figure 4. Percentage change from previous year: cases of personal grievance resolved through the Employment Tribunal}

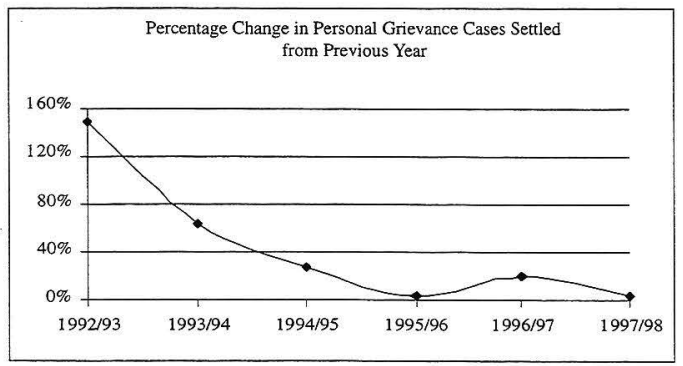


Figure 5. Cases of unjustified dismissal resolved through the Employment Tribunal

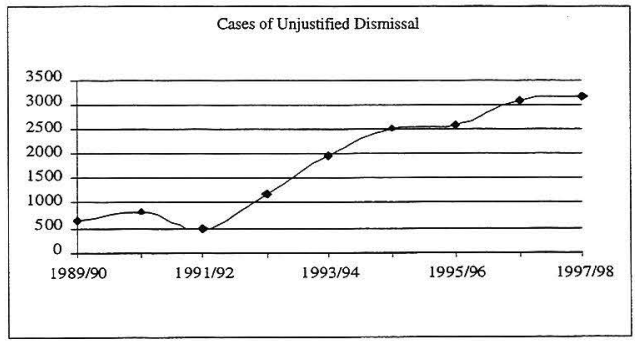

Breakdown of total personal grievances by category of grievance type

The total personal grievance numbers can be broken down and analysed according to the grounds for the personal grievance. That is, unjustified dismissal, disadvantage, sexual harassment, discrimination or duress. Unfortunately, it becomes difficult to use information prior to $1989 / 90$ due to differing categories and date reporting techniques. These categories will be discussed in order of proportion of total personal grievances. Hence unjustified dismissal will be discussed first (Figure 5), followed by disadvantage (Figure 6), and sexual harassment and discrimination together (Figure 7). As there is less than one duress case per year since 1989/90, often with several years between cases, it was pointless to produce a graph for this category. However, comments that relate to the sexual harassment and discrimination cases are pertinent to duress also.

Unjustified dismissal as a grounds for personal grievance has remained a very high proportion of total personal griev- ances, and as such, follows similar lines to the total (see Figure 5 above). It is possible that the number of unjustified dismissal cases actually drives the total personal grievance data line. This high proportion may relate to evidence that other types of potential personal grievances are often resolved in workplace. The Tribunal most often becomes involved when the employment relationship has broken down and subsequent dismissal has occurred. The intention is usually simply to negotiate a settlement at this point (Donald, 1998).

During the $1989 / 90$ and $1990 / 91$ years, unjustified dismissals hover at around $85 \%$ of personal grievances. In the 1991/ 92 year, the actual numbers dip in accordance with the total line, but the proportion jumps to $93 \%$. For the following five periods (1992/93 to 1996/97), the proportion of unjustified dismissals hovers around $97-96 \%$, while the actual numbers steadily increase with total personal grievances. In the $1997 / 98$ year, the number increased marginally, while the proportion dips marginally to $92 \%$ of the total, which is still higher than the pre-ECA proportion.

\section{Figure 6. Cases of disadvantage resolved through the Employment Tribunal}

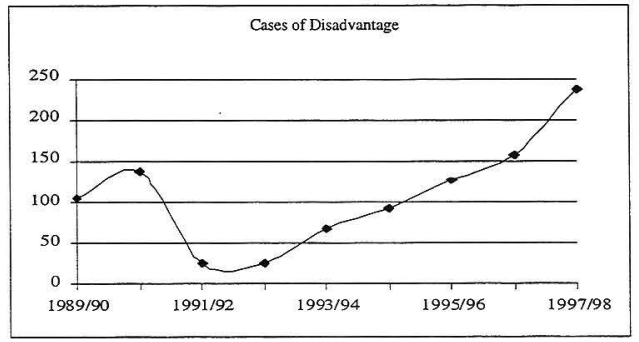




\section{Figure 7. Cases of sexual harassment and discrimination resolved through the Employment Tribunal}

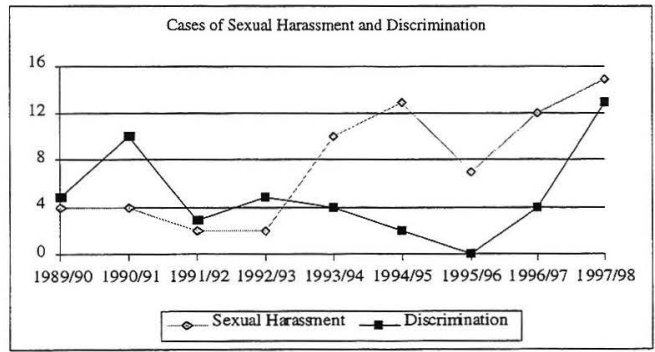

The 'dip' in cases after $1991 / 92$ is likely to be related to uncertainty in the manner for pursuing cases under the ECA. The rapid increases in unjustified dismissal cases after 1992/ 93 might be the result of more militant activity by employers following the ECA. Another explanation may be related to reforms to the social welfare benefit systems, which required recipients to be 'involuntarily' unemployed in order to receive the unemployment benefit without a large stand-down period. There are anecdotal reports that employees who have been fired will take a personal grievance case for unjustified dismissal to avoid the stand-down period that would normally be imposed by the welfare agencies for becoming 'voluntarily' unemployed.

The change in access to personal grievance provisions has widened the availability of personal grievance procedures from members of unions to all employees. This change has primarily affected white collar and managerial level workers who were less likely to be union members and would not have been eligible to take a personal grievance against their employer prior to the ECA. The large amount of economic gain that a white collar or professional employee can obtain through a successful personal grievance case against unjustified dismissal is likely to be a significant motivation.

The next category to examine is disadvantage. Although the number of disadvantage cases is significantly lower than unjustified dismissals, Figure 6 (previous page) shows a similar shape to both the total personal grievance and the unjustified dismissal lines. It appears more pronounced in this illustration because of scale.

The most notable characteristic of this graph is the large drop in the number of disadvantage cases resolved in the $1991 / 92$ year. This drop is in keeping with the overall decrease in personal grievances resolved potentially due to uncertainty with the new ECA. At this time, the proportion of total personal grievances resolved that were unjustified dismissals increased, hence the proportion of disadvantage personal grievances decreased. From 1992/93 to 1996/97 there is a steady increase in numbers of disadvantage personal grievances resolved. This is likely to be as industrial relations players come to terms with what constitutes disadvantage. Additionally, as with unjustified dismissals, the steady increase could be due to more militant activity by employers following the ECA. The 1997/98 year shows a significant rise, which contrasts with the lower rises in both unjustified dismissal and total personal grievances. This could signal a recent reduction in work conditions that have led to the need to take action.

Finally, the last classes of personal grievance considered in this paper are sexual harassment and discrimination. These categories have been graphed together due to the comparatively low numbers of both (Figure 7, above).

Figure 7 maps the numbers of sexual harassment and discrimination cases resolved by the mediation service (to 1991) and the Employment Tribunal (from 1991). While the absolute number of these types of cases over this period are small, the trends in the data sets are revealing. Cases of personal grievance related to discrimination peaked in the $1997 / 98$ year (at 13). Since 1990/91, discrimination cases seem to have followed a downward movement; with a low of zero discrimination cases being registered in 1995/ 96. Meanwhile, sexual harassment cases seem to have moved down after the passage of the ECA and then up since 1993/94.

The fluctuations in both these categories do not seem to follow the same overall patterns of the other lines. This could be due to the nature of these types of personal grievance. For instance, filing a sexual harassment personal grievance relates to the personal strength and value systems of the worker - a 'stronger' worker may 'fight' the employer legally where a 'weaker' worker may simply resign. These types of personal grievance can be very hard to 
prove and are much more emotional in content for all parties. Although actual numbers of sexual harassment cases generally increased from $1993 / 94$ to $1997 / 98$, the proportion of total personal grievances for the nine year period hovered around 0.4-0.5\% (the exception was $1992 / 93$ when other types of personal grievance increased sharply).

The patterns noted in the number of sexual harassment cases resolved may be the result of a number of factors. Sexual harassment cases arising from the workplace can be pursued either through the avenue of the Human Rights Commission or through a personal grievance. Where a sexual harassment case is pursued through the route of a personal grievance, the complaint is taken against the employer instead of the harasser (where they are different). This may have influenced the choices employees made about pursuing their case through the specialist employment institutions instead of the human rights avenues. An employee may choose not to file a personal grievance where the worker has a good relationship with the employer and the employer is not the harasser. Also, the numbers of personal grievance complaints relating to sexual harassment may be affected by the waiting time for a case to be investigated by the Human Rights Commission.

It is difficult to find a pattern in the discrimination cases. Of significance is the sudden rise in the $1997 / 98$ year to its highest point in the data represented. The relatively low number of discrimination cases resolved between 1992/3 and $1995 / 96$ may be the result of an adjustment period following the enactment of the ECA. Over this period, a move towards individual contracts has diminished the opportunity to determine differences in individuals' terms and conditions of employment. Another explanation for this relatively low level of cases resolved may be the effect of the ECA on unions. In particular, the reduced roles of unions in industrial relations may have reduced the level of institutional support for minority groups suffering discrimination.

\section{Method of resolution}

Just as the movement in the personal grievance categories themselves is undoubtedly crucial to understanding the current industrial relations system in New Zealand, so too is the method of resolution. Figure 8 (above) illustrates the proportion of personal grievances resolved through mediation as compared to adjudication.

From $1989 / 90$ to $1997 / 98$, the actual number and proportion of personal grievances resolved through mediation have steadily increased (with the exception of 1991/92 when the number decreased while the proportion increased). The biggest increases have been since the enactment of the ECA and following the re-election of the National Government in the 1994/95 year.

Conversely, from $1989 / 90$ to $1997 / 98$, the proportion of personal grievances resolved through adjudication has steadily decreased. The actual numbers fluctuated little from $1989 / 90$ to $1992 / 93$ (again with the 1991/92 exception). This was followed by a sharp decrease in 1993/94 that is consistent with the overall pattern of change. The number of adjudicated resolutions then gradually dropped by a total of 100 cases until $1997 / 98$ while the proportion steadily decreased.

The potential reasons for this pattern of preference for mediated resolutions include; first, that employers and employees could be taking more responsibility for their own resolution as they become more familiar or comfortable with the current industrial relations system. Also, this pattern suggests that the judiciary have put into practice their stated commitment to promote mediation as the prime means of grievance resolution (Skiffington, 1996).

\section{Summary}

Four significant patterns related to personal grievances have been identified in this paper. First is the high proportion of

\section{Figure 8. Proportion of resolutions through the Employment Tribunal by mediation and adjudication}

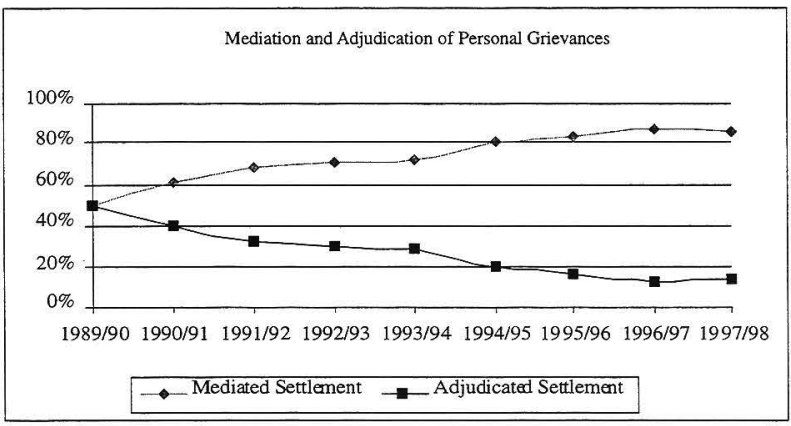


personal grievances that make up the Tribunal workload. Currently, $75 \%$ of all Tribunal cases are personal grievances. Second is the steady increase of personal grievances since the introduction of the ECA. Each year has seen an increase in actual numbers of personal grievances resolved, from 500 cases in $1991 / 92$ to 3418 cases in 1997/98. Next is the large proportion of personal grievances that are unjustified dismissal cases. Currently, $92 \%$ of all personal grievance cases resolved are on the grounds of unjustified dismissal. Finally is the steady increase in mediated outcomes. Currently, $86 \%$ of all personal grievance cases are resolved through mediation, and therefore, not eligible for appeal.

Personal grievances remain an important aspect of the New Zealand industrial relations system. With the current debate concerning the necessity and relevance of personal grievances, understanding recent phenomena is vital. The vast increase in personal grievances since the introduction of the ECA is indicative of New Zealand employees choosing to voice their situation through the legal system. Whether this is due to a perceived lack of alternatives or a reduced effectiveness of alternatives is difficult to identify at this stage.

It was not the intention of the authors to produce a paper that could 'conclude' with easy explanations for the phenomena occurring within the New Zealand personal grievance system over the last 14 years. Rather, the purpose of this paper was to expose those phenomena with possible explanations to generate discussion and encourage further research.

\section{Future research}

Much of the data needs to be precisely interpreted. This promises to be time-consuming research, with interviews or surveys of Tribunal administrators to facilitate explanation. A fruitful area of analysis may involve examining the number of cases resolved by the specialist institutions in relation to the amount of funding the government is providing to these institutions and according to their staffing and available resources. Other areas of analysis might include examining the trends in personal grievance cases lodged in light of the level of industrial activity experienced in the same year and according to levels of unemployment and the perceptions of the state of the business cycle.

\section{Sources and notes for figures}

\section{Figure 1}

House of Representatives Appendices: report of the Department of Labour (G. 1)

- for the years ended 30 June 1991/1992/1993/1994/1995/ $1996 / 1997 / 1998$

- for the six months ended 31 December 1991

Cases resolved by the Tribunal that were not in the category of personal grievances mainly include compliance orders, contract disputes, penalty actions, and recovery actions.

\section{Figure 2}

House of Representatives Appendices: report of the Department of Labour (G. 1)

- for the years ended 30 June 1991/1992/1993/1994/1995/ $1996 / 1997 / 1998$

Percentage change from the previous year is established via the following equation:

$$
\text { (b-a) } / a * 100 / 1 \text { where } a=\text { first year, } b=\text { second year. }
$$

\section{Figure 3}

House of Representatives Appendices: report of the Department of Labour (G. 1)

- for the years ended 30 June 1990/1991/1992/1993/1994/ $1995 / 1996 / 1997 / 1998$

- for the years ended 31 March 1983/1984/1985/1986/1987/ $1988 / 1989$

- for the six months ended 31 December 1989/1990/1991

Personal grievance cases were dealt with by the Industrial Conciliation Service and the Industrial Mediation Service until 1987 and then the Mediation Service between 1987 and 1991 at which point there was a transition to the Employment Tribunal

\section{Figure 4}

House of Representatives Appendices: report of the Department of Labour (G. 1)

- for the years ended 30 June 1991/1992/1993/1994/1995/ $1996 / 1997 / 1998$

Percentage change from the previous year is established via the following equation:

$(b-a) / a * 100 / 1$ where $a=$ first year, $b=$ second year.

\section{Figure 5}

House of Representatives Appendices: report of the Department of Labour (G. 1)

- for the years ended 30 June 1990/1991/1992/1993/1994/ $1995 / 1996 / 1997 / 1998$

- for the six months ended 31 December 1990/1991

These personal grievance cases were dealt with by the Mediation Service until 1991 at which point there was a transition to the Employment Tribunal.

\section{Figure 6}

House of Representatives Appendices: report of the Department of Labour (G. 1)

- for the years ended 30 June 1990/1991/1992/1993/1994/ $1995 / 1996 / 1997 / 1998$

- for the six months ended 31 December 1990/1991

These personal grievance cases were dealt with by the Mediation Service until 1991 at which point there was a transition to the Employment Tribunal.

\section{Figure 7}

House of Representatives Appendices: report of the Department of Labour (G. 1) 
- for the years ended 30 June 1990/1991/1992/1993/1994/ $1995 / 1996 / 1997 / 1998$

- for the six months ended 31 December 1990/1991

These personal grievance cases were dealt with by the Mediation Service until 1991 at which point there was a transition to the Employment Tribunal.

Employees have had the option of pursuing some of these claims through other instruments of the state e.g. discrimination linked to certain protected properties and sexual harassment claims could be pursued with the Human Rights Commission instead of taking a personal grievance

\section{Figure 8}

House of Representatives Appendices: report of the Department of Labour (G. 1)

- for the years ended 30 June 1990/1991/1992/1993/1994/ $1995 / 1996 / 1997 / 1998$

- for the six months ended 31 December 1990/1991

Prior to $1991 / 92$, personal grievance cases were heard by the Mediation Service; from 1991/92, personal grievances were heard by the Employment Tribunal.

Prior to 1991, the decisions of the chairperson in cases resolved by the mediation services are assumed to equate to adjudications. All other cases are assumed to be mediations.

\section{References}

Anderson, Gordon (1991) The Employment Contracts Act 1991: an Employers charter?, New Zealand Journal of Industrial Relations, vol. 16, no 2, August, pp. 127-142

Boxall, Peter (1993) Management strategy and the Employment Contracts Act 1991, pp.148-164, in Harbridge, Raymond (ed.) Employments Contracts New Zealand Experiences. Wellington, Victoria University Press.

Dannin, Ellen. J. (1997) Working Free: The Origins and Impact of New Zealand's Employment Contracts Act, Auckland University Press, Auckland.

Deeks, John., Parker, Jane and Ryan, Rose (1996) Labour and Employment Relations in New Zealand, second edition, Auckland, Longman Paul.

Department of Labour (1990-1998) The report of the Department of Labour to the House of Representatives (G. 1), for the years ended 30 June, 1990 1998, Wellington, GP.

Department of Labour (1989-1991) The report of the Department of Labour to the House of Representatives (G. I), for the six months ended 31 December, 1989-1991, Wellington, GP.

Department of Labour (1983-1989) The report of the Department of Labour to the House of Representatives (G. 1), for the years ended 31 March, 1983. 1989, Wellington, GP.
Donald, Dianne (1998) Unions and Personal Grievance Resolution: Managers of Discontent, Unpublished Dissertation, University of Waikato.

Grills, Walter (1994) The Impact of the Employment Contracts Act on Labour Law: Implications for Unions, New Zealand Joumal of Industrial Relations, vol. 19, no. 1, pp. 85-101, April.

Hughes, John (1993) Personal Grievances, pp. 89-133, in Harbridge, Raymond (ed.), Employment Contracts: New Zealand Experiences, Wellington, Victoria University Press.

Hughes, John (1991) The Employment Tribunal and the Employment Court, New Zealand Journal of Industrial Relations, vol. 16, no. 2, pp. 175-183, August.

Oldfield, Yvonne and Ryan, Rose (1991) Your Employment Contract, Wellington, Working Life Communications.

Skiffington, Lorraine (1996) The Role of Specialist Legal Institutions in Bargaining Under the Employment Contracts Act 1991: Saboteurs or Saviours, New Zealand Journal of Industrial Relations, vol. 21, no. 1.pp. 49-66, April.

Spell, C. (1998) The Evolution of Rights Disputes and Grievance Procedures: A Comparison of New Zealand and the U.S., California Western International Law Journal, vol.28, no. 1.

\section{Authors}

Dianne Donald is a Lecturer, and Joanna Cullinane is a $\mathrm{PhD}$ student at the Department of Strategic Management and Leadership, The University of Waikato,

Private Bag 3015,

Hamilton.

E-mail: dianned@waikato.ac.nz

E-mail: jmc1@waikato.ac.nz 